\title{
Hva feiler det den vanskelige pasienten?
}

\author{
Når objektive funn ikke kan forklare graden av plager, kan det være konstruktivt å sette søkelyset \\ på mestring og aksept.
}

Smerter og kroppslige plager som ikke kan forklares av objektive medisinske funn, står for opp mot en tredel av konsultasjonene i primærhelsetjenesten, er markant til stede i spesialisthelsetjenesten og er også assosiert med sykefravær (1-3). Begreper som medisinske uforklarte plager og symptomer, subjektive helseplager, sammensatte plager og funksjonelle lidelser brukes for å beskrive disse tilstandene.

Personer som tildeles diagnoser basert på slike tilstandsbilder, er i høy grad plaget, er ofte bekymret når de søker hjelp og bruker gjerne mye tid på å forstå og håndtere plagene sine (4). Subjektive helseplager som hodepine, nedstemthet, problemer med fordøyelsen, tretthet og muskelsmerter er vanlig (5). De aller fleste av oss har slike plager fra tid til annen, og det er ingen klar skillelinje mellom et normalt nivå og et nivå av plager som gjør at noen søker profesjonell hjelp. Men mange av dem som legen møter over lengre tid, har vesentlig høyere symptombelastning og mer redusert funksjonsnivå enn det vi kan regne som resultat av dagliglivets småplager (4).

Det kan være vanskelig for en lege som er vant til å forholde seg til objektive patologiske funn å være imøtekommende overfor en pasient som er sterkt plaget på tross av at de medisinske testene er normale (6). Om det er legen eller pasienten som driver frem ønsket om flere medisinske tester er uklart (7). I de tilfellene der legen tar initiativet, kan det være et uttrykk for mangel på terapeutiske verktøy.

Det er ikke uvanlig at personer som har helseplager uten objektive funn, føler seg avvist eller mener at de ikke blir forstått av

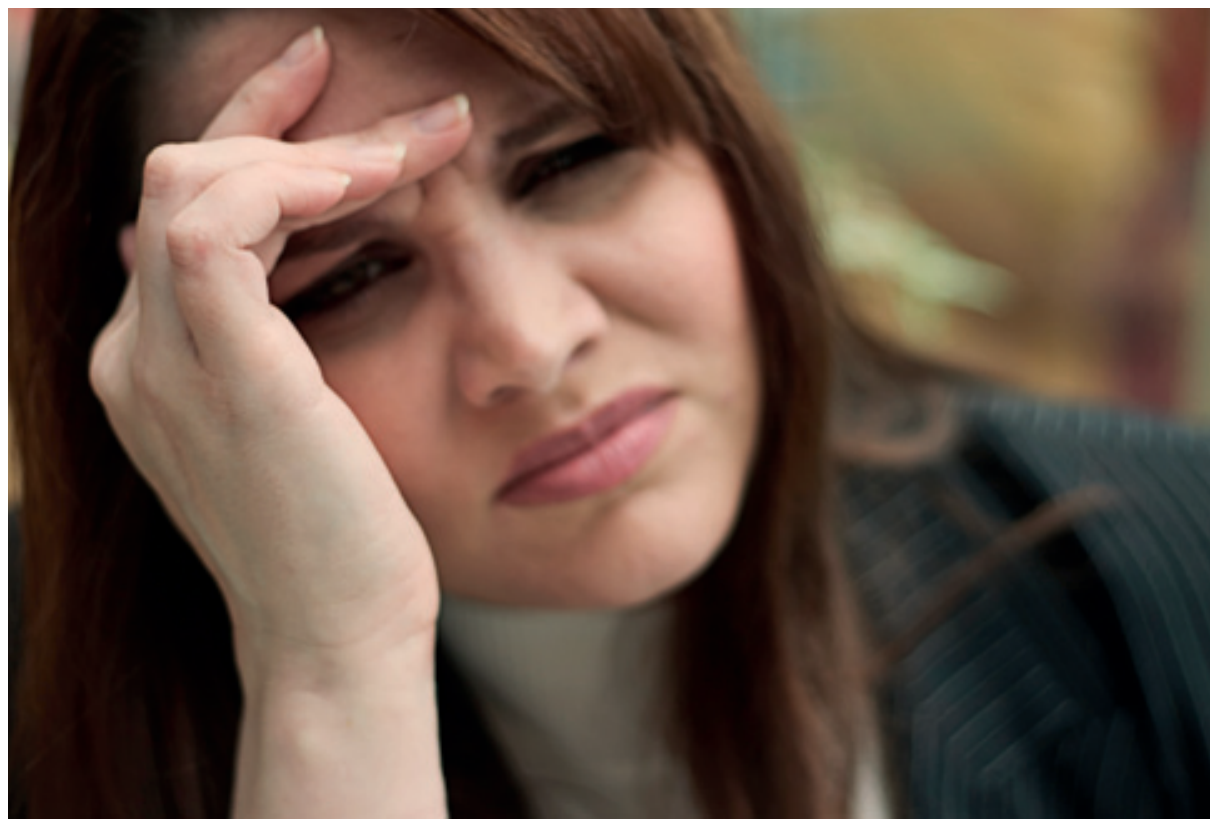

Illustrasjonsfoto Istockphoto

psykisk sykdom. Peter Prydz \& Kirsti Malterud har utviklet et undervisningsopplegg som tar for seg allmennlegens møte med disse pasientgruppene. De har rekonstruert tre konsultasjoner og gir konkrete eksempler på hvordan legen kan bidra. Når og hvordan funksjonelle diagnoser er til hjelp, er et annet viktig tema som blir diskutert (8).

Det er behov for mestring både hos leger og pasienter når det kommer til plager som ikke forklares av tradisjonell medisin. Alle kan vi føle oss syke selv om det ikke foreligger noen målbar patologi, men for noen

\section{«Det er behov for mestring både hos leger og pasienter når det kommer til plager som ikke forklares av tradisjonell medisin»}

helsevesenet. Samtidig kan denne gruppen oppleve seg krenket dersom plagene blir tilskrevet psykiske årsaker. I studier av angst og depresjon hos personer med høy grad av medisinsk uforklarte plager finner man at denne gruppen skårer signifikant høyere enn andre som regnes som friske eller har en sykdom med kjent somatisk årsak (1). Hvordan forholder man seg til denne motsetningen?

Løsningen kan ligge i å fokusere på mestring og aksept fremfor somatisk og kan dette i perioder oppleves som tilnærmet uutholdelig. Gode samarbeidsrelasjoner, der pasienten har lov til å ha det vanskelig, men samtidig blir hjulpet mot en meningsfull forståelse og bedre mestring av sine egne plager, må være et skritt i riktig retning.

\section{Anna Helle-Valle}

anna.helle-valle@uni.no

Uni research - Uni helse

Universitetet i Bergen
Anna Helle-Valle (f. 1984) er psykolog og stipendiat. Hun er også kjent som morgenkåsør i NRK P2.

Ingen oppgitte interessekonflikter.

\section{Litteratur}

1. Henningsen P, Zimmermann T, Sattel H. Medically unexplained physical symptoms, anxiety, and depression: a meta-analytic review. Psychosom Med 2003; 65: 528-33

2. Tveito TH, Halvorsen A, Lauvålien JV et al. Room for everyone in working life? $10 \%$ of the employees $-82 \%$ of the sickness leave. Norsk Epidemiologi 2002; $12: 63-8$.

3. Rosendal M, Olesen F, Fink P. Management of medically unexplained symptoms. BMJ 2005; 330 4-5.

4. Burton C. Beyond somatisation: a review of the understanding and treatment of medically unexplained physical symptoms (MUPS). Br J Gen Pract 2003; 53: 231-9.

5. Eriksen HR, Ihlebæk C. Subjective health complaints. Scand J Psychol 2002; 43: 101-3.

6. Wileman L, May C, Chew-Graham CA. Medically unexplained symptoms and the problem of power in the primary care consultation: a qualitative study. Fam Pract 2002; 19: 178-82

7. Salmon P, Ring A, Dowrick CF et al. What do general practice patients want when they present medically unexplained symptoms, and why do their doctors feel pressurized? J Psychosom Res 2005: 59: 255-62

8. Prydz P. Malterud K. Fra usikkerhet til mestring. En undervisningsvideo om MUPS for allmennleger. Oslo/Bergen: Den norske legeforening/Uni helse, 2011. www.legeforeningen.no/id/167672 (18.8.2011).

Mottatt 18.5. 2011, første revisjon innsendt 19.7. 2011, godkjent 18.8. 2011. Medisinsk redaktør Anne Kveim Lie. 